\title{
BUSINESS ANALYSIS BASED ON THE CONCEPT OF THREE DIRECTIONS - CONFIRMED QUALITY IN OPERATIONS AND FINANCIAL REPORTING
}

\author{
Borka Sokoloski*, Igor Zdravkoski \\ University “St. Clement Ohridski” - Bitola, Faculty of Economics, Gorce Petrov bb, Prilep, Macedonia
}

\section{Abstract:}

It is generally well-known that many people perform some kind of analysis at different times, no matter if it relates to their private or business lives, such as when buying an apartment, house, car and alike. That implies investigating and examining details, comparing the quality and price. Actually, we assess what we can get for a certain amount of money, or what will happen if we invest in real estate or a car, variations of interest rates in different banks.

Namely, the operations of enterprises, execution of tasks and obligations and goal achievement can be successfully managed and implemented only by a well-structured and conducted business analysis. Once the problem arises in operations of enterprises, the business analysis triggers necessary procedures and processes in order to solve, mitigate or overcome them. It does not depend on the problems, phenomena and processes in business operations. The purpose of business analysis is to successfully detect irregularities in operations, remove such possible flaws and irregularities and guarantee better conditions.
\end{abstract}

\section{INTRODUCTION}

"The examination of the past is necessary for achieving greater prosperity in the future, because you can only improve what you know."

Todor Stojanovic

"Business analysis is observation, examination, assessment and formulation of diagnosis in all the processes that have occurred in the enterprise and their description."

B. Sokoloski - I. Zdravkoski

Business analysis is part of the economic analysis that examines and analyses the overall business sector. That is to say, enterprises with their totality are the subject of the analysis. Hence, we come to the fact that, all phenomena, parts, performance and resources that occur may be subject to analysis. We shall particularly emphasize that the company and its operations in all of its functions are the basis of any business analysis. In the context of the above-stated, we shall quote prof. Sokoloski, who says: "In analyzing the operation of enterprises one should start from the fact that the company - as a complex organism that develops and operates within the entire economy of which it is a part - is a dynamic and complex system in which many interactive links between individual subsystems appear, as well as between those subsystems and the system as a whole." (Sokolski, 2014) Undoubtedly, businesses (enterprises, companies, trade associations, etc.) represent the holding of an economy. This means that the operation of enterprises is an economic process that strives for rational behavior and use of resources, and that means, analyzing not only the work performed in the earlier period, but also an ongoing analysis and the analysis for the upcoming period.

Taking this into consideration, we will emphasize two aspects of the analytical testing, including the following:

- The subject of examination are the previous operations of the company whose task is to determine and evaluate the achieved results in order to find out the reasons for determined positivity and negativity in the operation, which would allow for greater success in carrying out the tasks and decision making in the future,

- The subject of examination is the plan and the company's work in the future, where you set the hypothesis that shall realize the goals and achieve optimal results. 
In both cases we have the same ultimate goal, coming up to the level of achieving better business results, i.e. higher financial results - profit. Additionally, an important thing that should be stressed out is the dynamics and static (as one moment of interrupted dynamics) of the subject of analysis and its environment. But also quantity vs. quality, where business analysis performs a permanent process of transforming quantity into quality. Accordingly, business analysis as a subject of analyzing objectives is the factor that affects the operations of enterprises, such as external and internal, then organizational and economic units, the functions performed in them, separate procedures and processes, capital investment and business results and success of the enterprise. Namely, business analysis aims to investigate and analyze the operations of the enterprise in a certain period of time, examining the individual sections broken down, and determine the causes of abnormalities in the operation as well as propose measures for their removal and measures to reinforce the positivities of the work performed. Hence, we see that business analysis appears as a continuous process that is carried out in enterprises in cases of positive, but also in cases of negative financial results. Having considered the above-mentioned, the questions arises as to who is requesting the analysis. The answer is simple: the analysis is requested by the stakeholders. The most important stakeholders are the following: owners of companies, shareholders, creditors, auditors, tax authorities, economic journalists and others. These customers require a range of different information and indicators of financial performance, where the creditors (banks, savings banks etc.) are interested in the creditworthiness of the business entity, shareholders are interested in profit and dividend they are entitled to, the tax authorities are interested in respecting legal norms, or determination of the tax base, creditors for settlement of claims, while owners perceive and determine opportunities for improvement and enterprise development etc. This confirms that business users require the analysis of the financial "health" of the enterprise which is the ultimate goal of all business entities.

\section{BUSINESS ANALYSIS AND BUSINESS DECISION MAKING}

Despite a large number of interested parties regarding the business analysis, it is necessary to make special reference to the management team that of all stakeholders benefit most from quality performed business analysis. In order to make operation of enterprises efficient and effective, the top-managers should make optimal decisions on the basis of decisions made by managers who perform other functions of the company, constantly monitoring the performance and establishing quick feedback via the letters if they perceive certain deviations in the work processes that cannot be tolerated. After all, modern business decision making is based on accurate and timely information that reaches the managers who will make the final decision relying on their experience. Hence, you can tell that business analysis is the basis for making proper business decisions. According to Peter Drucker, we can distinguish five phases in the decision making process, as follows:

1. Defining the problem,

2. Analyzing the problem,

3. Developing alternative solutions,
4. Selection of the optimal alternative,

5. Transforming decision into an effective action.

The analysis also occurs in each of the above-mentioned phases, which means that it is necessary to perceive and process the analysis during the preparation and adoption of decisions. In that sense, the first phase - the defining of the problem is determining the purpose and the task of the analysis. While the second stage of analyzing the problem, is the execution of the analysis. The analysis itself includes a breakdown of the analysis subject down to its components, in order to examine the quantity and quality of those parts and of course, to determine the actual condition of certain changes, impacts etc. Furthermore, the third phase, the development of alternative solutions, reflects the synthesis. In the fourth stage, a selection of the most valuable solution is made out of the proposed alternative solutions. The adoption and installation of the solution in action-action represents the fifth stage. Namely, each analysis, hence the business analysis too, in the foreground has a preventive character as well, thus it tends towards correct decisions in the working process and its implementation in the best possible way. In fact, the analysis examines the reasons, confirms the facts, calculates and finds all possible new solutions to improve the integrity of the enterprise. It means that the constructive work, rationality and positive financial results can be improved, modernized and increased. It reflects on the facilitation of the work of the employees themselves, managers, as well as easier distribution of tasks within business entities.

\section{BUSINESS ANALYSIS APPROACH THROUGH "CONCEPT - THREE DIRECTIONS"}

Surely, we confirmed that business analysis serves to make timely and correct business decisions, both in terms of the plan and engagement of production factors and their more rational and better utilization through the process of reproduction, and deciding regarding work in the future. Because of this, it is necessary to move towards more analytical procedures, which ensure permanent application of the deduction methods based on the thorough research and getting to the initial indicators. In fact, a complex procedure starts regarding the breakdown of the company's operations in individual areas, i.e. running and performing analysis by the concept of three directions. This means that the company's operations are analysed by:

Business success, in order to identify the dynamics and success of the enterprise,

- The terms of management, perception of external and internal conditions under which business results are realized,

- The distribution of profits and in what form are business results distributed.

Classically, the set analysis shows the generally accepted scheme which, in today's market conditions and democratic processes of functioning imposes the need to use the concept of three directions. That is, depending on the needs and standards of comparison, deep analytical procedures are conducted and each procedure has its own purpose. This can be best seen in Figure 1 (Sokolski, 2014).

Considering the foregoing, we can emphasize that the business analysis is the process of monitoring, testing, evalu- 


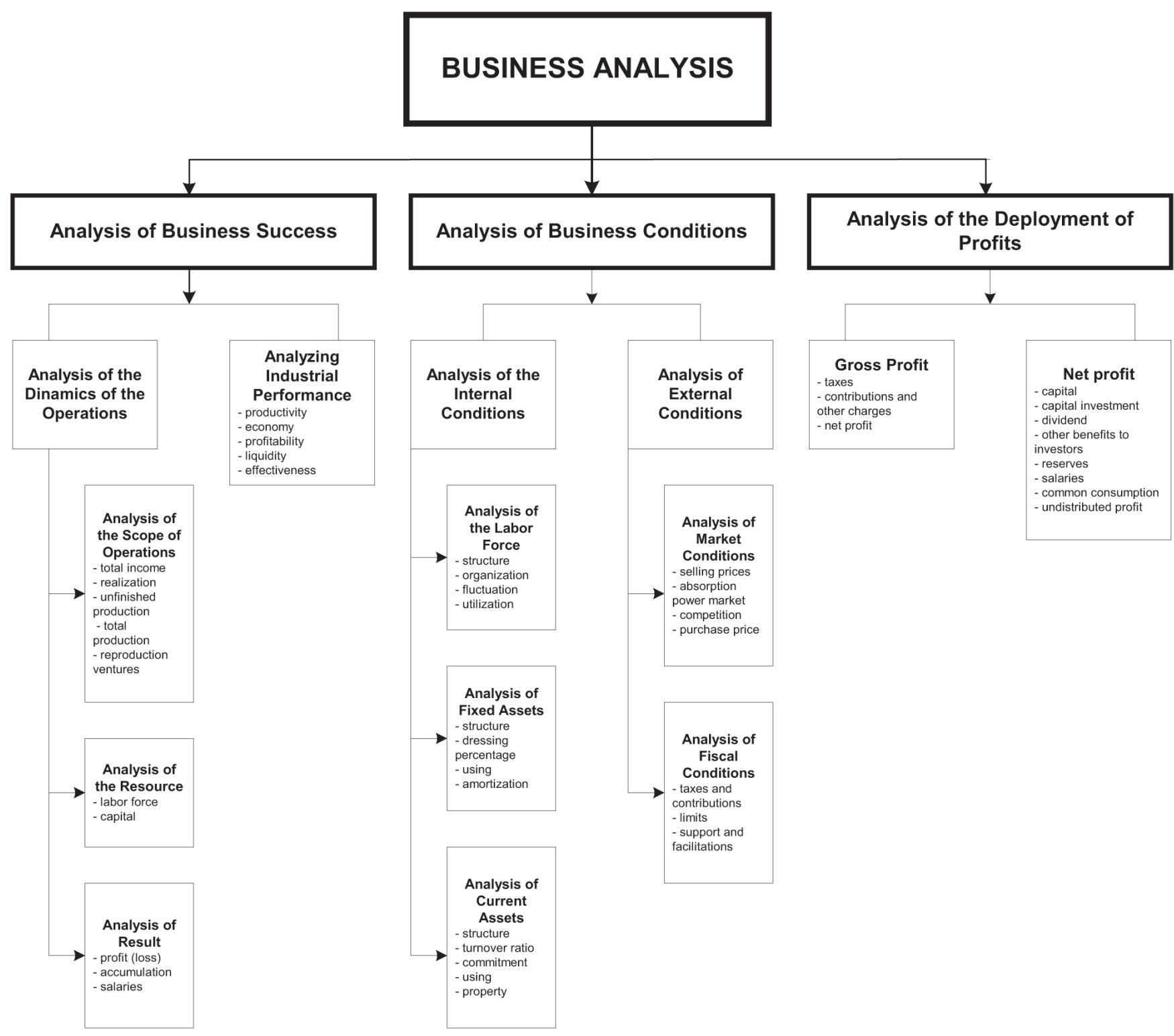

Figure 1. Business analysis approach through concept - three directions, regarding the operation of the enterprise.

ation and formulation of diagnosis in all processes that have occurred in the enterprise and their description. Also, business analysis developed under the concept of three directions gives objective results, identifies the most hidden flaws and mistakes that occurred intentionally or unintentionally in the business entity. At the same time, it includes and performs the comparative analysis and determines the places where weaknesses appear, as well as certain shortcomings and delays. Indicators that reveal all the flaws in the company's work are synthesized in the result obtained as a general conclusion and acceding to a diagnosis, i.e. the "therapy" that will be used to treat side effects and the prognosis which will determine the approach and the period of "recovery" thereof. In the final phase of the conducted business analysis and the initial stage of planning, the concept of three directions provides quality answers and solutions that can be rational alternative approaches to achieving the greatest possible results. Lastly, we specifically emphasize that business analysis is an organized, systematic and continuous function performed by the professionals for successful realization of the planned tasks and achievement of greater business results.

\section{CONCLUSION}

The performances of all individual sectors of modern enterprises are affected by joint networking of different types of information.

Namely, the significant role of information during the companies' performance can be of crucial importance.

In fact, the channels used for obtaining information vary for different types of information.

Therefore, the application of business analysis through the concept of three directions provides:

- Exploring and analysis of an enterprise and its main components (administration, working plants, equipment, etc.);

- Analysis of financial statements by which information are summarized and through precise financial indicators that facilitate the decision making process is facilitated;

- Analysis of business results (periodically or annually);

- Analysis of the business environment and working conditions in order to foster competition; 
- Analysis of operations and detecting possible risk, minimization of risk and undertaking measures for risk removal;

- Analysis of accounting-information sector, and obtaining objective, validated and comprehensible data and information;

- Analysis of the quality of production, labor, equipment etc.

Particularly, the analysis based on the concept of three directions covers individual parts and performs a breakdown to their smallest elements.

In order to get precise data and information on the condition and quality of this analysis, it is of crucial importance to perform the concept of three directions.

Finally, we highlight the advantages that are gained by using the concept of three directions:

- Firstly, modernization of financial reporting in the company to facilitate the decision-making process;

- Secondly, minimizing the errors and operational risks;

- Thirdly, improvement of accounting and information system;

- Fourthly, improvement of production quality;

- Fifthly, verification and confirmation of business results;

- Sixthly, creating better working conditions and clear picture of the professional and employed staff; and,

- Seventhly, the assessment of conditions for capital investments and expansion of enterprise capacities.

\section{REFERENCES}

Block, S., \& Hirt, G. (2008). Foundation of Financial Management. New York: McGraw-Hill/ Irwin Companies Inc.

Drucker, P. (1954). The Practice of Management. New York: Harper \& Brothers.

Horngren, S., \& Elliott, P. (2006). Introduction to Financial Accounting. USA: Pearson Education.

Palepu, K. G., \& Healy, P. M. (2004). Business Analysis \& Valuation- Using Financial Statements. Mason, $\mathrm{OH}$ : Thomson South-Wester.

Reilly, B. (2000). Investment Analysis and portfolio Management. Orlando, FL: Dryden.

Sokoloski, B. (2014). Business analysis: script. Prilep: Faculty of economics.

Stojanović, T. (1990). Analysis of the operation of enterprises. Skopje: UAFA.

White, G., Sondhi, A., \& Fried, D. (1998). The Analisys and Use of Financial Statements. New York: Wiley \& Sons.

Wild, J.J., Larson, K.D., \& Chiappetta, B. (2009). Fundamental Accounting Principles. New York: McGraw-Hill/ Irwin Companies Inc.

Zdravkoski, Z., \& Zdravkoski, I. (2004). Accounting: study and practice. Prilep: Faculty of economics.

\section{ANALIZA POSLOVANJA NA OSNOVU TRI KRITERIJUMA POSLOVANJA: POTVRDA KVALITETA POSLOVANJA I FINANSIJSKOG IZVEŠTAVANJA}

\section{Apstrakt:}

Opšte je poznato da mnogi ljudi u različito vreme sprovode neku vrstu analize, bez obzira na to da li se ona odnosi na njihov privatni ili poslovni život, npr. kupovinu stana, kuće, automobila, ili slično. To obuhvata istraživanje i proveru detalja, upoređivanje kvaliteta i cena. Zapravo, procenjuje se ono što možemo da dobijemo za određenu sumu novca, ili šta će se desiti ukoliko investiramo u nekretninu ili auto, koliki je iznos kamate u različitim bankama.

Uspešno sprovođenje predviđenih zadataka i ciljeva, kao i nesmetano funkcionisanje preduzeća, može se postići samo putem dobro sprovedene analize poslovanja. Čim nastane problem u fukcionisanju preduzeća, neophodno je pokrenuti procedure i procese kako bismo ga prepoznali i prevazišli. Analiza poslovanje je nezavisna od problema, pojave i procesa u poslovanju. Cilj analize jeste da uspešno dijagnostikuje nepravilnosti tokom rada, ukloni nedostatke i stvori bolje operativne uslove.

\section{Ključne reči:}

rezultati,

informacije,

odluke. 